\title{
Converting Traditional Production Systems to Focused Cells as a Requirement of Global Manufacturing
}

\author{
Ibrahim H. Garbie \\ Department of Mechanical and Industrial Engineering, Sultan Qaboos University, Muscat, Oman. \\ Email: garbie@squ.edu.om
}

Received January $30^{\text {th }}, 2011$; revised April 20 ${ }^{\text {th }}, 2011$; accepted May $12^{\text {th }}, 2011$.

\begin{abstract}
The converting process from traditional production systems (e.g., Job Shops) to focused (cellular) systems is important as one requirement of global manufacturing to challenge the existing global financial crisis. This represents a big problem and a huge task for manufacturers and academicians which almost most of industrial enterprises around the world are still working as a job shop. This converting process means breaking or dividing the existing functional (process) layout into independently and distinctly focused manufacturing cells to gain on the conversion benefits. To consider this issue, a new methodology of converting job shops into cellular systems is introduced based on the requirements of global manufacturing regarding manufacturing systems design only. These requirements are: responsiveness, reconfigurable machines, mass customization, innovative and manufacturing systems configuration. A complete industrial case study will be used to analyze and explain the proposed methodology in a small-sized job shop manufacturing firm.
\end{abstract}

Keywords: Reconfigurable Manufacturing Systems, Cellular Manufacturing Systems, Cell Formation.

\section{Introduction}

Due to an increasingly competitive global market, the need for shorter product life cycles and time to market, and diverse customers, changes in manufacturing systems have been tried to improve the flexibility and productivity of manufacturing systems. There are three different types of manufacturing systems: flow shop (mass production) system, batch production system, and job shop manufacturing system. The job shop manufacturing system is characterized by high flexibility and low production volume and uses general-purpose machines. The flow shop manufacturing system has less flexibility due to dedicated machine tools but more production volume is valuable. Due to the limitations of job shop and flow shop systems to accommodate fluctuations in product demand and production volume, manufacturing systems are often required to be reconfigured to respond to changes in product design, introduction of a new product, and change in product demand and volume. As a result, cellular manufacturing systems (CMS) have emerged as promising alternative manufacturing systems to deal with these issues especially for next period as a competence for the global manufacturing as one solution to solve this crisis in industrial enterprises [1].

CMS design is an important manufacturing concept involving the application of group technology and it can be used to divide a manufacturing facility into several groups of manufacturing cells. This approach means that similar parts are grouped into part families and associated machines into machine cells, and that one or more part families can be processed within a single machine cell. The creation of manufacturing cells allows the decomposition of a large job shop manufacturing system into a set of smaller and more manageable subsystems. There are several reasons for converting traditional manufacturing system (e.g., Job Shop systems) into cellular systems. These reasons include reduced work-inprocess (WIP) inventories, reduced lead times, reduced lot sizes, reduced inter-process handling costs, better overall control of operations, improved efficiency and flexibility, utilized space, reduced operation costs, improved product design and quality, and reduced setup times. General descriptions of group technology and cellular manufacturing systems, cell formation techniques, 
and an extensive review of the various aspects adopted for cellular manufacturing systems are discussed carefully in the literature review [2].

Always, a new product is requested and demanded at low price with high quality and highly customized (mass customization). For surviving in the globalization, a new configuration of the manufacturing systems lead to launch new products to market replacing old ones competing in low prices and high quality. So, the reconfiguration from Job shop system to cellular systems has become an issue of core competence. Reconfigurable Job Shop manufacturing systems must take into account the mass customization requirements which they can cope with unpredictable environment changes to adapt with productivity and flexibility issues to change their configuration and physical layout. Resources (e.g., machines, material handling equipments, etc.) should be adjusted and composed in a changeable structure. These resources should be modular machines such as: CNC machines and/or reconfigurable machine tools [3].

Usually, the Job shop manufacturing systems cannot be completely divided into focused cells. Reasonably, a portion of the Job shop facility remains as a large especially in mid-sized and large-sized systems. Functional job shop system that has been termed the "functional or reminder cell" and the cellularization may be less than $100 \%[4,5]$ and around $60 \%$ [6]. The entire manufacturing system cannot be completely converted into cellular cells and typically around $40 \%-50 \%$ of total production system can be transferred [7]. Hybrid organizations for next period which consist of functional departments and manufacturing cells were recommended [8]. The main objectives of reconfiguring existing Job shop manufacturing systems into cellular systems are system performance measures (productivity and flexibility) to satisfy market demand and management goals.

The remainder of this paper is organized as follows. Section 2 reviews the research mainly related to conversion from job shop manufacturing systems to cellular systems and manufacturing cells formation. The globalization issues will be discussed in Section 3. Section 4 presents the proposed conversion. A complete industrial case study will be explained with the results and discussion in Section 5. The conclusions and recommendations for further work are given in Section 6.

\section{Literature Review}

There are significant amounts of literature review dedicated to the design of cellular manufacturing systems (CMS) over the last four decades since 1973. Conversion from an existing job shop manufacturing system to a cellular manufacturing system was presented through modeling and economic analysis by SIMAN software simulation package [9]. The production flow analysis was used to convert job shops to manufacturing cells [10]. Benefits and limitations due to conversion from a functional layout to a cellular layout were presented [11]. A bi-criterion technique based on the flexibility and efficiency in converting functional manufacturing systems into cellular manufacturing systems was presented [12]. Redesigning functional production systems into cellular systems was mentioned through similarity order clustering between machines [13]. Improving productivity through converting job shops manufacturing systems to cellular systems using optimal layout configuration [14]. The reconfiguration costs and times were approximately estimated. A lot of cell formation techniques were recommended to convert job shops manufacturing system to cell systems [15].

A pragmatic approach was proposed to grouping machines and parts in CMS to achieve cell independence as a goal function [16]. A simulated annealing was presented to minimize cell load imbalance and extra capacity required [17] while the simulating annealing was used to increase the productivity in CMS [18]. A clustering approach based on similarity coefficient which includes production sequence and product volumes to form a manufacturing cell $[19,20]$. Branching rules to group machines into machine cells and parts into part families was used [21]. A heuristic approach for cell formation was suggested to generate manufacturing cells [22]. Mathematical programming techniques were used to form cell formation incorporating machine capacity, alternative routing and identical machines to achieve cell independence [23,24]. A heuristic cell formation incorporating alternative routing, operation sequence, processing times, production volume, and machine capacity was presented [25]. New similarity coefficients were proposed to group parts into independent flow-line families considering machine capabilities and operations sequences [26]. A mathematical programming technique was presented to form manufacturing cells by considering alternative routing and identical machines [27]. A integer programming to minimize intercellular movements and machine costs considering multiple time periods was developed [28,29]. A flexible cell formation approach was presented by considering routing and demand flexibility [30]. Operations sequence to minimize cost of materials flow and capital investment for designing CMS was used [31].

Average linkage clustering algorithm for grouping parts (products) into part (product) families was used [32, 33]. They considered effectiveness of a Reconfigurable Manufacturing System (RMS) depends on the formation of best set of product families. The reconfiguration issues in manufacturing systems were introduced mainly on 
reconfiguring existing cellular system to another cells taking into consideration system utilization and throughput [34]. A reconfiguration link was suggested to interface between market requirements and manufacturing facilities to group products into families and select the appropriate family at each configuration stage [35]. A routing flexibility was used as a contingency process routings in formation of manufacturing cells versus additional costs of duplicate machines [36,37]. Axiomatic design (AD) and experimental design (ED) are used as a framework to complete cellular manufacturing system design [38] to generate several feasible and potentially profitable designs. A new methodology was presented to optimize resource through balancing the workload in designing cellular manufacturing systems as a solution for flow shop environments [39]. The design of CMS based on tooling requirements of the parts and tooling available on the machines was proposed and presented [40]. A traditional clustering formula to evaluate the effectiveness of cell formation as a performance measure was used [41]. Machine reliability through alternate routing process versus transporting, operating, and underutilized costs is suggested in design of CMS $[42,43]$. Although there are a myriad of optimal cell formation techniques proposed to cell design, they none seem to address the most of relevant globalization issues or on the other words, most of the research works done in this field has been focused on clustering or forming rather than converting from existing job shop manufacturing systems.

In this paper, a comprehensive converting approach from functional and/or process layout to cellular layout will be introduced incorporating the most important globalization issues regarding manufacturing systems design. Also, practical performance measuring will be evaluated.

\section{Globalization Issues}

Several relevant globalization issues should be taken into consideration when designing global manufacturing systems and/or as a requirement of converting functional cells into focused cells. These issues are discussed as follows:

\subsection{Responsiveness}

Responsiveness is the time required by a machine to perform an operation on a part type. Sometimes, responsiveness is considered as a manufacturing lead time. Normally, set up time and processing times are included in manufacturing lead time. The processing time should be provided for every part (product) on corresponding machines in the operation sequence. Processing time is important because it is used to determine resource (machine) capacity requirements [2]. Hence, ignoring the processing times may violate the capacity constraints and thus lead to an infeasible solution [44].

\subsection{Reconfigurable Machines}

Manufacturing systems use reconfigurable machines representing in components and architecture which can offer a much greater range of options to manufacturers. Reconfigurable machines are considered into two main issues: machine capacity and machine capability.

\subsubsection{Machine Capacity}

Machine capacity is the amount of time a machine of each type is available for production in each period. When dealing with maximum possible demand, we need to consider whether the resource capacity is violated or not. In the design of cellular systems for reconfiguration, available capacities of machines need to be sufficient to satisfy the production demand $[2,43]$. Machine capacity is more important and it should be ensured that is more adequate capacity (in machine hours) is available to process all the part families [45]. The importance of machine capacity is being rapidly adjusted to fluctuations in changing product demand.

\subsubsection{Machine Capability}

Machine capability refers to the functionality of machines to perform varying operations without incurring excessive cost from one operation to another. The machine level is fundamental to a manufacturing system, and machine flexibility is a prerequisite for most other flexibilities as mentioned by $[1,30,45]$.

\subsection{Innovation}

Introducing a new product or product design and development (modification) represents a new concept when the CMS should be designed. Although they carry overlapping definitions to design CMS, incorporating one of them will develop concepts of CMS from traditional ideologues to advanced ideologues (agile systems) [46, 47]. To achieve these new concepts, reconfiguring traditional job shop systems into cellular systems with customized flexibilities is highly desired. As the reconfiguration manufacturing systems is one of most important strategies in achieving agility in the manufacturing systems, reconfiguring or reorganizing not only the traditional job shop systems but also the cellular system [43]. Introducing a new product or changing in existing product design (product development) will base on the machine flexibility and machine reliability.

\subsection{Mass Customization}

Demand is the quantity of each product in the product mix to be produced in each period. The product demand of each product is expected to vary across the planning 
horizon. Changing in product demand and the variability in parts demands lead the designers of manufacturing systems to convert the job shop systems to cellular systems. Mass customization does not mean producing one of a kind product but to producing relatively large quantities of varieties of products from the same product family at mass production competitive of economics scale. The goal of mass customization is to increase customer's value of a product by adding a range of product variations that fit specific customer's taste and needs while maintaining low prices [48]. Producing products for mass customization presents a challenge because of substantial changes in product flexibility and product volume (demand).

\subsection{Manufacturing System Configuration}

The configuration of a manufacturing system can facilitate the system's productivity and responsiveness. Facility location and facility layout are the system configuration requirements for global manufacturing. In this paper, facility layout is considered. A designer of manufacturing systems should consider cell configurations and system configurations. Reconfigurable machines intra-cells and/or inter-cell are necessary especially during next period.

\section{Converting Methodology}

The proposed methodology for converting Job Shop manufacturing systems to focused cells will be introduced into five phases. The objective of first phase is used to collect data of existing parts (products) and machines from existing Job Shop manufacturing system. The second phase is to group parts into part families according to similarity in processing requirements. Distributing part families to machines will be assigned in third phase according to part(s) specification. Formation of manufacturing cells, including part families with machine cells will be introduced in fourth phase. In fifth phase, formed manufacturing cells will be evaluated and revised.

\subsection{Phase 1: Collecting the Existing Data from Job Shop Manufacturing Systems}

It should analyze carefully existing Job shop manufacturing systems into different perspectives such as existing parts and machines information analysis. For parts (products) information analysis, it should include number of jobs or products (sometimes called lot size), number of machines required for each part (product), processing or manufacturing time from each operation, demand (lot size) of each one. For machines information analysis, it also should include number of machines in a plant, how many manufacturing departments, and how many different types of machines in each department and the specification of each machine. Also, it should exactly know a machine capacity and machine flexibility (capability).

\subsection{Phase 2: Grouping Parts to Part Families}

Parts are assigned to part families according to the similarity in processing requirements between two parts (products). A procedure to group parts into part families will be explained in following steps:

Step 1: Compute the similarity coefficient matrix between all parts according to the following Equation (1): where: $S_{p q}=$ similarity coefficient between part type $p$ and part type $q, D_{p}(t)=$ demand of part type $p$ at time $t, D_{q}(t)=$ demand of part type $q$ at time $t, k=$ subscript of parts $(k=1, \cdots, n), m_{c}=$ total number of machines in the $c$ th cell, $m=$ number of machines in the job shops manufacturing system, $m_{x_{p q}}=$ number of machines that both part $p$ and part $q$ visit, $n_{c}=$ total number of parts in the $c$ th cell, $t_{l p}=$ processing time part $p$ takes on machine $l, t_{l q}=$ processing time part $q$ takes on machine $l, X_{p q l}=1$, if part type $p$ and part type $q$ visit machine $l, X_{p q l}=0$, otherwise, $Y_{p q l}=1$, if part type $p$ or part type $q$ visits machine $l, Y_{p q l}=0$, otherwise

Step 2: Determine the desired number of part families (NPE) by the following equation:

$$
N P F \leq \frac{n}{n_{\text {min }}}
$$

where: $n=$ number of parts in existing Job shop manufacturing systems, $n_{\min }=$ minimum number of parts in a part family.

Step 3: Select the largest similarity part $p$ and part $(q, \cdots, n)$ to start grouping the first part family .Check for the minimum part family size (at least one part per family). Decrease the value of similarity index to group the second part family. Also, form a new part family according to the lower similarity. Check to determine if some parts have not been assigned to part families.

\subsection{Phase 3: Assigning Machines to Machine Cells}

Machine cells involve assignment of machines into ma-

$$
S_{p q}=\frac{\sum_{l=1}^{m_{X_{p q l}}} \max \left[t_{l p} D_{P}(t), t_{l q} D_{q}(t)\right] X_{p q l}}{\sum_{l=1}^{m_{X_{p q l}}} \max \left[t_{l p} D_{P}(t), t_{l q} D_{q}(t)\right] X_{p q l}+\sum_{l=m_{X p q l}}^{m-m_{X p l}}\left[t_{l p} D_{P}(t), O R t_{l q} D_{q}(t)\right] Y_{p q l}}
$$


chine cells based on the new similarity coefficient between two machines. A similarity coefficient between machines will base on processing time of all part type operations, number of operations performed, machine capability (flexibility) and machine capacity (reliability), and demand of each part (product). A procedure to group machines into machine cells will be explained in following steps:

Step 4: Check the machine balancing at any time $M B(t)$ of each machine type capacity $\left[C_{1}(t), C_{2}(t), \cdots, C_{m}(t)\right]$ to produce all parts (products) demands $\left[D_{1}(t), D_{2}(t)\right.$, $\left.\cdots, D_{n}(t)\right]$ by these machines in job shop manufacturing systems. The $M B$ of machine $i$ at any given time $t$ is based on demand rates and processing times of all parts (products) assigned to machine $i$. The equation for computing $M B$ for machine $i$ is shown as a following Equation (3)

$$
M B_{i}(t)=\sum_{k=1}^{n} t_{k i} D_{k}(t)
$$

Step 5: Compute the similarity between all machines according to the following Equation (4).

where: $S_{i j}=$ Similarity coefficient between machines $i$ and $j, C_{i}(t)=$ capacity of machine $i$ at time $t, C_{j}(t)$ = capacity of machine $j$ at time $t, D_{k}(t)=$ demand of part type $k$ at time $t, l=$ subscript of machines $(l=$ $1, \cdots, m), \quad n_{o_{i}}=$ number of operations done on machine $i$, $n_{o_{j}}=$ number of operations done on machine $j, N_{O_{i}}$

$=$ maximum numbers of operations available on machine

$i$ (machine capability) at time $t, N_{O_{i}}=$ maximum number of operations available on machine $j$ (machine capability) at time $t, n_{X_{i j}}=$ number of parts that can visit both machines $i$ and $j, t_{k i}=$ processing time part $k$ takes on machine $i$ including setup time.

$t_{k i}=$ processing time part $k$ takes on machine $j$ including setup time, $n_{X_{i j k}}=1$, if part type $k$ visits both machines $i$ and $j, X_{i j k}=0$, otherwise, $Y_{i j k}=1$, if part type $k$ visits either machine $i$ or machine $j, Y_{i j k}=0$, otherwise.

Step 6: Determine the desired number of machines cells ( NMC ) by the following Equation (5).

$$
N M C \geq \frac{m}{m_{\max }}
$$

$m_{\max }=$ maximum number of machines into machine cell.

Step 7: Select a highest similarity index between machine $i$ and machine $(j, \cdots, m)$ to start forming the first machine cell. Check the minimum machine cell size constraint (at least two machines per cell). Decrease a value of similarity index to form a new machine cell or add machines to the existing one. Check for a maximum number of machines in a machine cell. If number of machines in this machine cell does not exceed the desired number of machines, then, add to this cell. Otherwise, stop adding to this cell and go back to select another similarity index. If number of machine cells formed exceeds desired number of machine cells $N M C$, join two machine cells into one machine cell. If all machines have not been assigned to machine cells, assign a functional cell(s).

\subsection{Phase 4: Formation of Manufacturing Cells}

Step 8: Manufacturing cells are formed by grouping parts into part families and machines to machine cells. The corresponding manufacturing cells based on results obtained from Phase 2 and Phase 3 was formed by distributing part families to associated machine cells.

\subsection{Phase 5: Performance Evaluation}

Step 9: Compute exceptional parts and bottleneck machines.

\subsubsection{Productivity Measures}

Step 10: Machine $i$ utilization in cell $c$ at time $t$, $M U_{i c}(t)$, is evaluated as the following Equation (6).

$$
M U_{i c}(t)=\frac{\sum_{k=1}^{n_{c}} t_{k_{i c}} D_{k}(t)}{C_{i c}(t)}
$$

where $C_{i c}(t)$ capacity of machine $i$ in cell $c$ at time $t$, $t_{k_{i c}}(t)=$ processing time part $k$ takes on machine $i$ in cell $c, n_{c}=$ number of parts produced in cell $c$.

Step 11: Cell utilization at time $t, C U_{i c}(t)$, is estimated as the following Equation (7).

$$
C U_{c}(t)=\frac{1}{m_{c}} \sum_{i=1}^{m_{c}}\left(\frac{\sum_{k=1}^{m_{c}} t_{k_{i c}} D_{k}(t)}{C_{i c}(t)}\right)
$$

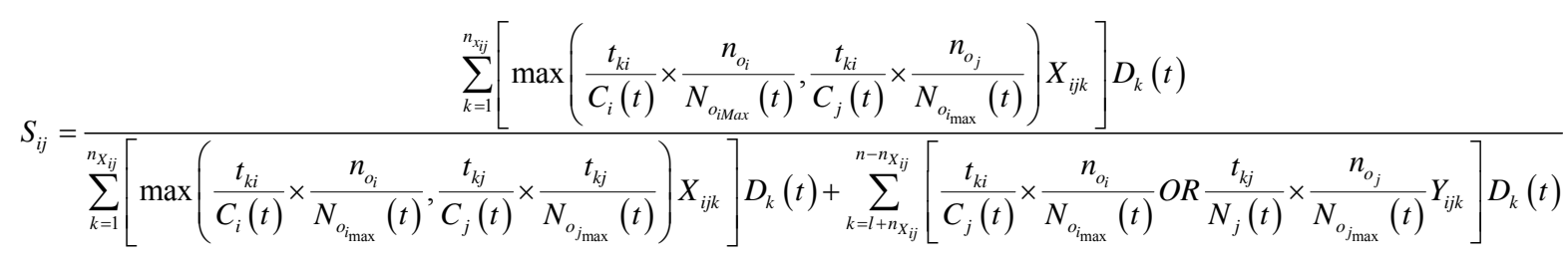


where $m_{c}=$ number of machines inside cell $c$.

Step 12: Cellular system utilization at any given time $t$, $S U(t)$, is calculated as an average cell utilization and depends on number of manufacturing cells in system. The $S U(t)$ is calculated as the following Equation (8).

$$
S U_{i c}(t)=\frac{1}{C(t)} \sum_{c=1}^{c(t)} \frac{1}{m_{c}} \sum_{i=1}^{m_{c}}\left(\frac{\sum_{k=1}^{m_{c}} t_{k_{i c}} D_{k}(t)}{C_{i c}(t)}\right)
$$

where: $C(t)=$ number of manufacturing cells at time $t$.

\subsubsection{Flexibility Measures}

Step 13: Machine flexibility $(M F L X)$ inside a cell after forming the manufacturing cells will be assessed by the machine processing capability and capacity (reliability). This flexibility will be used to measure capability of a machine [45] and it is expressed in the following Equation (9).

$$
M F L X_{i c}(t)=\sum_{\substack{0=1 \\ k=1}}^{n_{o_{i}}} \frac{\left(S M C_{i c}(t)\right)}{C_{i c}(t)} \times\left(\frac{\left(S M F_{i c}(t)\right)}{N_{O_{i c_{\max }} i c}(t)}\right)
$$

$\operatorname{MFL} X_{\text {ic }}(t)=$ flexibility measure of machine $i$ in manufacturing cell $c$ at time $t$.

$S M C_{i c}(t)=$ slack in machine capacity $i$ in manufacturing cell, $S M C_{i c}(t)=C_{i c}(t)-M B_{i c}(t)$

$$
M B_{i c}(t)=\sum_{k=1}^{m_{c}} t_{k_{i c}} D_{k}(t)
$$

$S M F_{i c}(t)=$ slack in machine capability $i$ in manufacturing cell, $S M F_{i c}(t)=N_{O_{i c_{\max }} i c}(t)-n_{o_{\text {ic }}}$.

$N_{O_{i c_{\max } i c}}(t)=$ maximum number of operations on machine $i$ in manufacturing cell $c$.

$n_{o_{i c}}=$ number of operations on machine $i$ in manufacturing cell $c$.

\section{Step 14: Cell flexibility}

After forming the manufacturing cells, cell flexibility (CFLX) will be assessed by the number of machines inside the cell. This flexibility is used to evaluate the manufacturing cell flexibility [45] and it is expressed in the following Equation (10).

$$
\operatorname{CFLX}(t)=\frac{1}{m_{c}} \sum_{i=1}^{m_{c}} \sum_{\substack{0=1 \\ k=1}}^{n_{o_{i}}}\left(\frac{S M C_{i c}(t)}{C_{i c}(t)}\right) \times\left(\frac{S M F_{i c}(t)}{N_{O_{i c_{\max }} i c}(t)}\right)
$$

\section{Step 15: Cellular System flexibility}

After forming the manufacturing cells, new product (part) flexibility (CSFLX ) will be assessed by the flexibility of cells in the system. Cellular system flexibility [45] can be used to test the cellular formation after assigning part families to machine cells for accepting one or more new parts (products) and it is expressed in the following Equation (11).

$$
\operatorname{CSFLX}(t)=\frac{1}{C(t)} \sum_{C=1}^{C(t)} \frac{1}{m_{c}} \sum_{i=1}^{m_{c}} \sum_{\substack{0=1 \\ k=1}}^{n_{o_{i}}}\left(\frac{S M C_{i c}(t)}{C_{i c}(t)}\right) \times\left(\frac{S M F_{i c}(t)}{N_{O_{i c_{\max }} i c}(t)}\right)
$$

\section{Case Study and Implementation}

XYZ Co., Inc., a manufacturing company for customer service, is located in Houston, Texas. XYZ Co. produces different types of parts (products) which are used in other manufacturing companies according to customer's requests. These parts are requested by the customers by identifying the quantity of each part (job) accompanied by engineering drawing or prototype of the part. This company has several machine tools, from conventional machines to Computerized Numerical Control (CNC) machines, for general purpose.

The main objective of this case study is to demonstrate the application and usefulness of the proposed manufacturing cells design approach for conversion and/or reconfigure the traditional job shop manufacturing systems to cellular systems. In the XYZ Co., Inc. machines were analyzed to identify the manufacturing cells that were included in the plant by determining the number of them. The number of machines with the identifying number of identical machines will also be identified. The specification of machines regarding machine capacity and capability will also be presented. Information with respect to parts produced in the XYZ Co., Inc., will be selected based on the number of parts (jobs) processed during the same time period. The processing times of these parts on machines with the sequence of operations were taken from the "Work Order Hours Report" for the set up time and processing time.

\subsection{Machines Information Analysis}

To analyze the machines in the layout, the number of machines in the plant was divided into five manufacturing departments. Three departments were used conventional machines (Lathe or turning (1) department, Lathe (2) department, and milling machines department). There are other two departments including all the CNC machines. It can be noticed in lathe department (1) that there are two different types of lathe machines with a total of 7 machines. Five similar machines are such as L (1)-A-A-L (2)-L (3), and two similar machines are such as L (4)-B. Also, in the lathe department (2), there are two different types of lathe machines with a total of 5 machines. Two similar machines are such as: L (5)-L (6) and three similar machines are such as: C-C-L (7). For milling department, there are six identical universal milling machines such as D-D-M1 (8)-D-D-M2 (9). 
There are two different $\mathrm{CNC}$ departments. One CNC lathe department includes five different $\mathrm{CNC}$ turning centers with a total of 6 machines such as: E-F-CNCL (10)-G-L-L. The other CNC milling department includes four different $\mathrm{CNC}$ vertical machining centers with a total of 6 machines such as H-I-CNCVMC (11)-J-KCNCVMC (12). Machine specification data regarding the machines' capacities and capabilities will be shown in Table 1. In this table, there are 12 machines that are used to process the 14 parts (products). These machines are $\mathrm{L}$ (1), L (2), L (3), L (4), L (5), L (6), L (7), M (8), M (9), CNCL (10), CNCVMC (11), and CNCVMC (12). The existing job shop manufacturing system plant layout is illustrated in Figure 1. It can be noticed from Figures 1 and 2 that part 6 proceeds through lathe (1) department and $\mathrm{CNC}$ lathe department. Part 7 proceeds through three departments: lathe (2), milling, and CNC milling. Also, part 8 needs three departments to be completed: lathe (1), lathe (2), and milling. Finally, part 9 needs also three departments: lathe (1), lathe (2) and milling.

\subsection{Products (Parts) Information Analysis}

To analyze jobs information, the number of parts in a plant was collected based on existing number of parts during the same period. There are 14 parts in processing during this period and 746 parts (products) on a waiting list. Table 2 presents the data of 14 parts on machines by identifying processing times, sequence, and quantity of parts (products).

\subsection{Machines-Parts Information Analysis}

To analyze machines-parts information, it is recommended to use the machine-part incidence matrix because it is considered an easiest way to represent processing requirements of the 14 parts on 12 used machines types (see Figure 3). It can be noticed that part 1 needs 57.2 minutes to process one unit (part) on universal milling machine [(M1 (8)].

\subsection{Application of the Conversion Methodology}

To demonstrate the application of the proposed cell de-

Table 1. Machines Information.

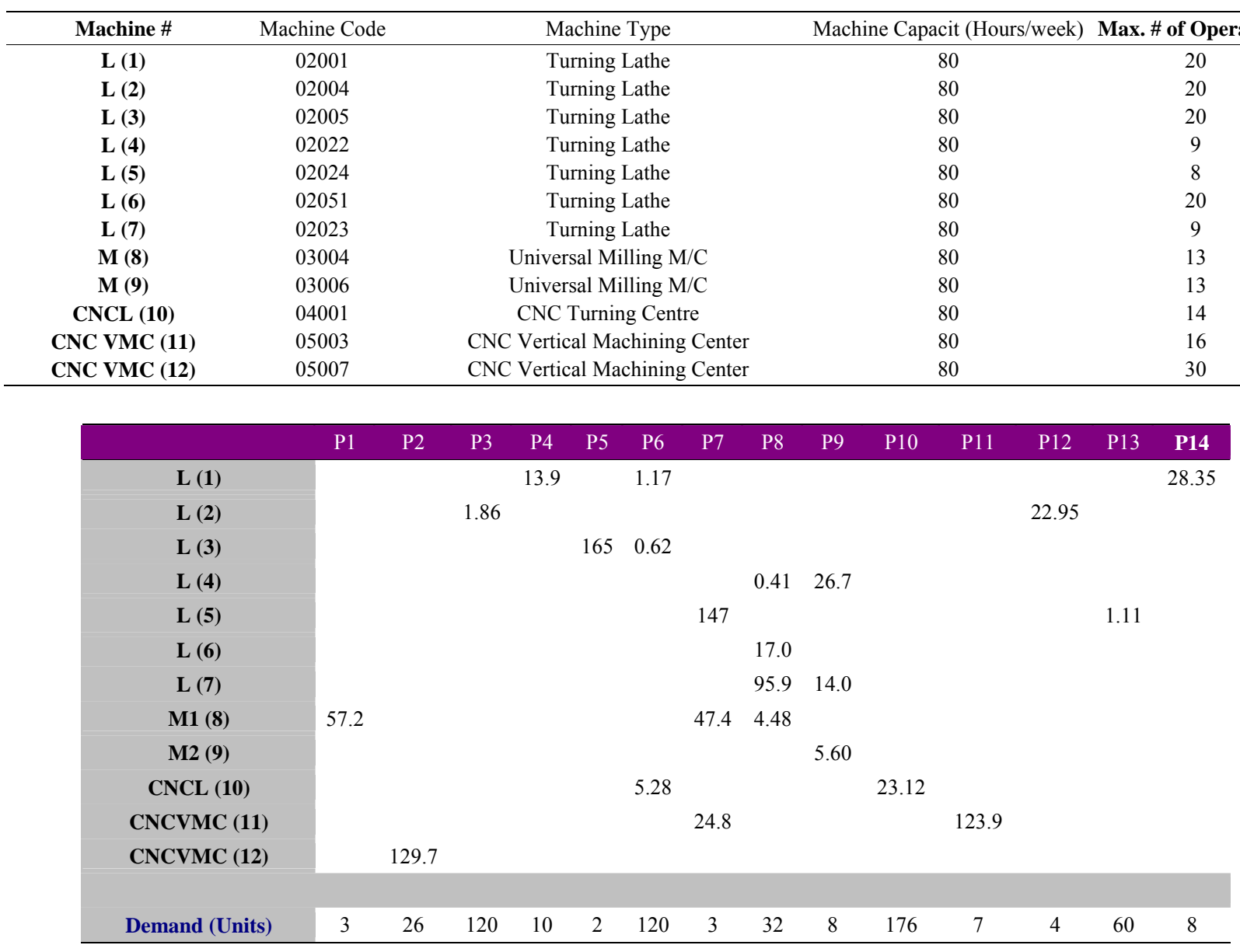

Figure 1. Machine-part incidence matrix. 

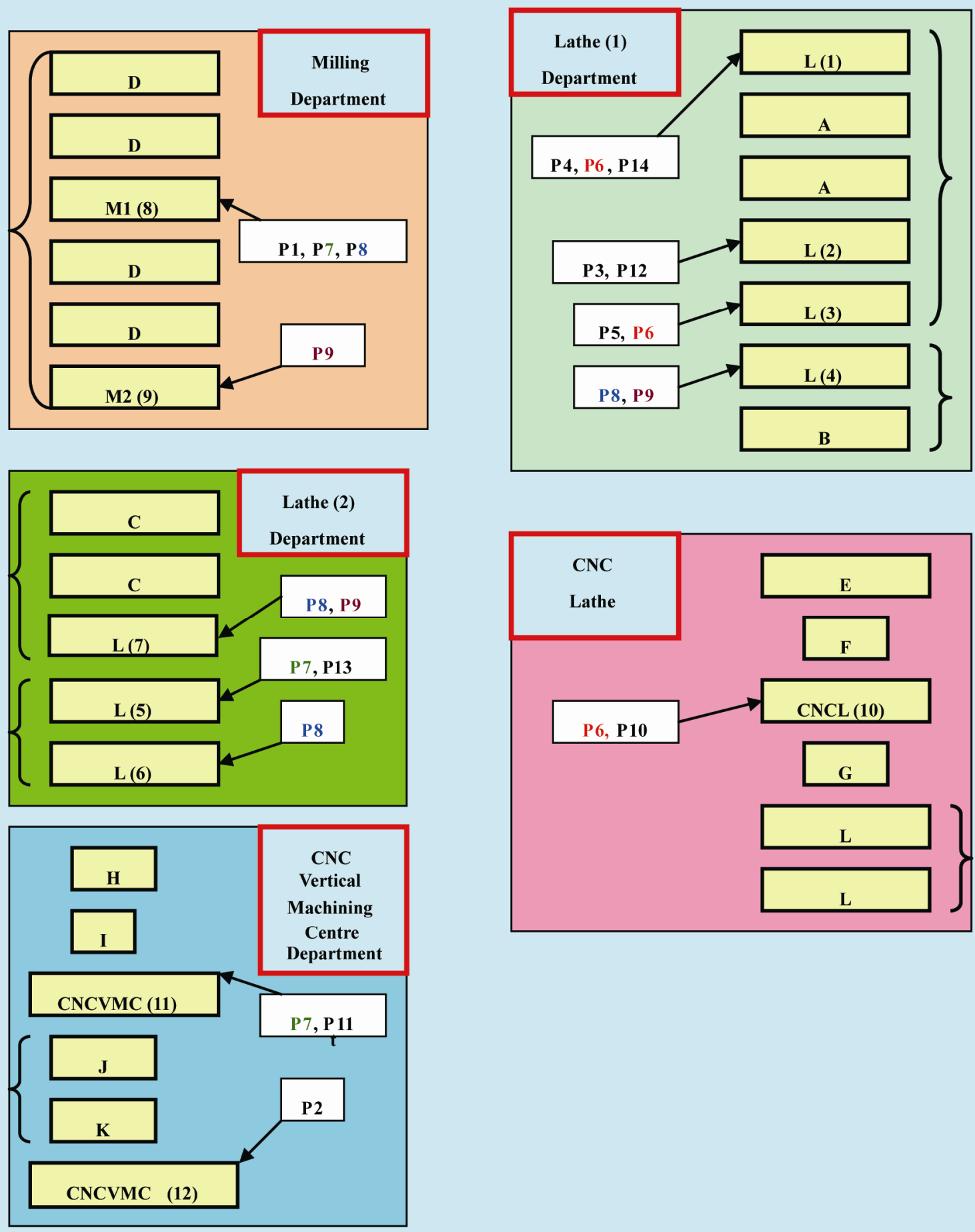

Figure 2. Existing job shop manufacturing system layout.

sign regarding the reconfiguration from job shop manufacturing systems into cellular systems, it should follow the sequence of procedures. This sequence can be represented in the similarity in processing requirements between parts and between machines, clustering machines into machine cells, grouping parts into part families, forming manufacturing cells, and evaluating performance. The final machine cells and part families will be shown as follows: Machine cell \# 1: $\{1,2,3,10\}$, Machine cell \# 2: $\{4,5,6,7,8,9,11,12\}$, Part family \# 1: $\{3,12\}$, Part family \# 2: $\{4,14\}$, Part family \# 3: $\{5,6,10\}$, Part family \# 4: $\{8,9\}$, Part family \# 5: $\{1,7,13\}$, Part family 
Table 2. Products information.

\begin{tabular}{cccc}
\hline Part \# & Sequence (Machines) & Processing Time (minutes) & Demand (Lot Size) \\
\hline $\mathbf{1}$ & M1 (8) & 57.2 & 3 \\
$\mathbf{2}$ & CNCVMC (12) & 129.7 & 26 \\
$\mathbf{3}$ & L (2) & 1.86 & 120 \\
$\mathbf{4}$ & L (1) & 13.9 & 10 \\
$\mathbf{5}$ & L (3) & 165.0 & 2 \\
$\mathbf{6}$ & L(1)-L(3)-CNCL (10) & $1.17-0.62-5.28$ & 120 \\
$\mathbf{7}$ & L(5)-M1 (8)-CNCVMC (11) & $147.0-47.4-24.8$ & 3 \\
$\mathbf{8}$ & L(4)-L(6)-L(7)-M1 (8) & $0.41-17.0-95.9-4.48$ & 32 \\
$\mathbf{9}$ & L(4)-L(7)-M2 (9) & $26.7-14.0-5.60$ & 8 \\
$\mathbf{1 0}$ & CNCL (10) & 23.12 & 176 \\
$\mathbf{1 1}$ & CNCVMC (11) & 123.9 & 7 \\
$\mathbf{1 2}$ & L (2) & 22.95 & 4 \\
$\mathbf{1 3}$ & L (5) & 1.11 & 60 \\
$\mathbf{1 4}$ & L (1) & 28.35 & 8 \\
\hline
\end{tabular}

Table 3. Formed manufacturing cells.

\begin{tabular}{|c|c|c|c|c|c|c|c|c|c|c|c|c|c|c|}
\hline Manufacturing cell & \multicolumn{12}{|c|}{ Machine cells (machines) } & \multicolumn{2}{|c|}{ Part Families } \\
\hline 1 & \multicolumn{12}{|c|}{ L (1), L (2), L (3), CNCL (10) } & \multirow{2}{*}{\multicolumn{2}{|c|}{$\begin{array}{l}\text { PF1, PF2, PF3 } \\
\text { PF4, PF5, PF6 }\end{array}$}} \\
\hline 2 & \multicolumn{12}{|c|}{ L (4), L (5), L (6), L (7), M1 (8), M2 (9), CNCVMC (11), CNCVMC (12) } & & \\
\hline & \multicolumn{2}{|c|}{ PF1 } & \multicolumn{2}{|c|}{ PF2 } & \multicolumn{3}{|c|}{ PF3 } & \multicolumn{2}{|c|}{ PF4 } & \multicolumn{3}{|c|}{ PF5 } & \multicolumn{2}{|c|}{ PF6 } \\
\hline & P3 & $\mathrm{P} 12$ & $\mathrm{P} 4$ & P14 & P5 & P6 & $\mathrm{P} 10$ & P8 & P9 & $\mathrm{P} 1$ & $\mathrm{P} 7$ & P13 & $\mathrm{P} 2$ & P11 \\
\hline $\mathrm{L}(1)$ & & & 13.9 & 28.35 & & 12.17 & & & & & & & & \\
\hline $\mathrm{L}(2)$ & 1.86 & 22.9 & & & & & & & & & & & & \\
\hline L (3) & & & & & 165 & 0.62 & & & & & & & & \\
\hline CNCL (10) & & & & & & 5.28 & 23.12 & & & & & & & \\
\hline
\end{tabular}

\begin{tabular}{|c|c|c|c|c|c|c|c|c|c|c|c|c|c|c|}
\hline L (4) & & & & & & & & 0.41 & 26.7 & & & & & \\
\hline $\mathrm{L}(5)$ & & & & & & & & & & & 147 & 1.11 & & \\
\hline L (6) & & & & & & & & 17.0 & & & & & & \\
\hline $\mathrm{L}(7)$ & & & & & & & & 95.9 & 14.0 & & & & & \\
\hline M1 (8) & & & & & & & & 4.48 & & 57.2 & 47.4 & & & \\
\hline M2 (9) & & & & & & & & & 5.60 & & & & & \\
\hline CNCVMC11 & & & & & & & & & & & 24.8 & & & 123.9 \\
\hline CNCVMC12 & & & & & & & & & & & & & 129.7 & \\
\hline Demand (Units) & 120 & 4 & 10 & 8 & 2 & 120 & 176 & 32 & 8 & 3 & 3 & 60 & 26 & 7 \\
\hline
\end{tabular}

Figure 3. Final formation of manufacturing cells.

\# 6: $\{2,11\}$, The Final manufacturing cells will be shown (see Figure 3), and then the manufacturing cells are two (see Table 3).

Measuring performance evaluation of manufacturing cell design will depend on the productivity and flexibility issues in different levels (machine, cell, system). The results will be shown in Table 4. It can be noticed from then results that there are six part families and two machine cells. Also, it can be noticed that there are three part families were assigned to each machine cell. This means that each machine cell can be process more than one part family. This will lead to say that reconfigure Job shop manufacturing system is expected not only to accommodate for production of a variety of products which are grouped into part families, but also it must give a significant response to deal with introducing a new product within each family [45]. It can be noticed that there is no exceptional parts and bottleneck machines in this case. May be this application has a limited number of parts and machines.

To compare the existing job shop manufacturing system and the new manufacturing cells design, the number of machines will be a major criterion. This represents the major contribution regarding why reconfiguration of ex- 
Table 4. Performance measures of the proposed manufacturing cells design.

\begin{tabular}{|c|c|c|c|c|c|c|c|}
\hline & \multicolumn{3}{|c|}{ Machine } & \multicolumn{2}{|c|}{ Cell } & \multicolumn{2}{|c|}{ System } \\
\hline & Machine Type & $\begin{array}{c}\text { Machine } \\
\text { Utilization }\end{array}$ & $\begin{array}{l}\text { Machine } \\
\text { Flexibility }\end{array}$ & $\begin{array}{c}\text { Cell } \\
\text { Utilization }\end{array}$ & $\begin{array}{c}\text { Cell } \\
\text { Flexibility }\end{array}$ & $\begin{array}{c}\text { System } \\
\text { Utilization }\end{array}$ & $\begin{array}{c}\text { System } \\
\text { Flexibility }\end{array}$ \\
\hline \multirow{4}{*}{1} & L (1) & 0.1056 & 0.7602 & \multirow{4}{*}{0.3089} & \multirow{4}{*}{0.6105} & \multirow{12}{*}{0.2753} & \multirow{12}{*}{0.6078} \\
\hline & L (2) & 0.0656 & 0.8408 & & & & \\
\hline & L (3) & 0.0846 & 0.8238 & & & & \\
\hline & CNCL (10) & 0.9797 & 0.0173 & & & & \\
\hline \multirow{8}{*}{2} & L (4) & 0.0472 & 0.7410 & \multirow{8}{*}{0.2416} & \multirow{8}{*}{0.6051} & & \\
\hline & L (5) & 0.1058 & 0.6705 & & & & \\
\hline & L (6) & 0.1137 & 0.8419 & & & & \\
\hline & L (7) & 0.6626 & 0.2621 & & & & \\
\hline & M1 (8) & 0.0952 & 0.6959 & & & & \\
\hline & M2 (9) & 0.0093 & 0.9144 & & & & \\
\hline & CNCVMC (11) & 0.1962 & 0.7032 & & & & \\
\hline & CNCVMC (12) & 0.7028 & 0.0120 & & & & \\
\hline
\end{tabular}

isting Job shop to focused cells are more important all the time because there is a reduction in capital investment through minimizing the number of machines used in the plant. They can be used in other places in new plants. The new plant layout can be shown in Figure 4. It can be noticed from Figures $\mathbf{3}$ and $\mathbf{4}$ that there are a big difference in the number of machines in each plant layout. From this study, it can be noticed that there are reduction or improvement in plant layout, reduced in inter-process handling costing. The number of work-in-progress is also reduced by $80 \%$ than the Job shop systems.

\section{Conclusions and Recommendation for Future Work}

This paper presented a new concept for converting traditional Job shop manufacturing systems into focused cells

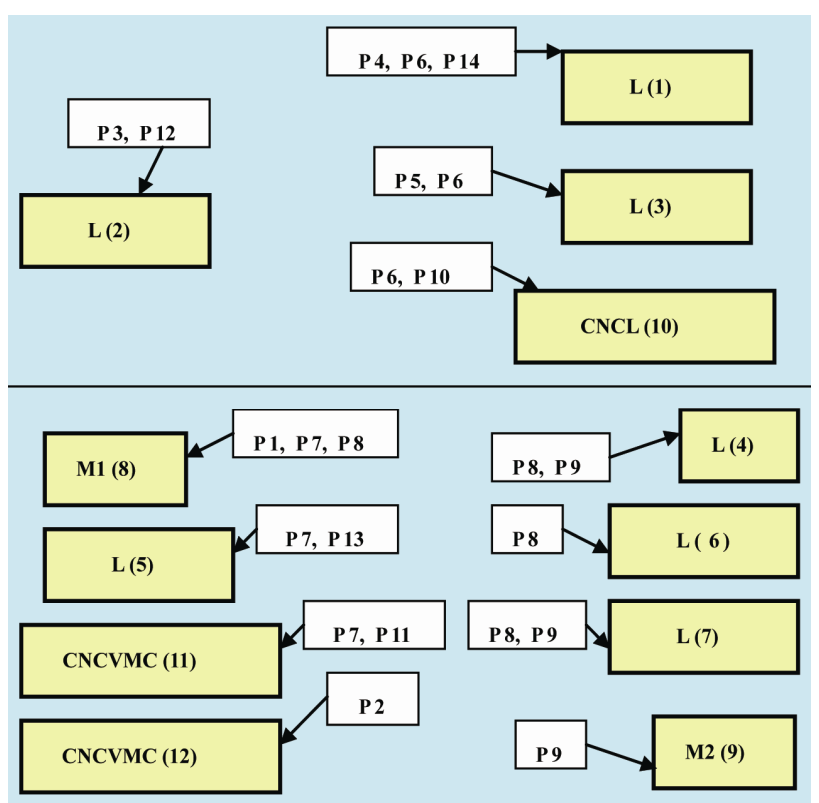

Figure 4. The proposed manufacturing cells design layout. systems based on the globalization issues. Globalization issues were proposed in this paper, and they will lead to suggest a new reconfiguration process. The proposed methodology of converting was introduced sequentially beginning grouping parts (products) into part families and assigning machines to those part families. Hence, the manufacturing cells were formed. The proposed methodology of conversion was examined with an industrial case study for its justification. The results show that there are main differences between the existing Job shop manufacturing system and focused cells which are considered the core of the new innovative manufacturing systems which can are used easily to apply lean manufacturing and agile manufacturing/management philosophies.

The main contribution in this paper is how to convert conventional Job shop manufacturing systems to focused cells although most of plants (factories) in the world are still working as the job shop system (functional or process layout). The author intends to extend this research for more applications in real case studies in next period especially under existing depression (global recession) in helping in reducing capital investment or saving or install machines in other plants.

\section{Acknowledgements}

The author would like to acknowledge the financial support provided by the Sultan Qaboos University (Grant No. $\mathrm{IG} / \mathrm{ENG} / \mathrm{MIED} / 10 / 01$ ) to carry out this research work.

\section{REFERENCES}

[1] I. H. Garbie, "A Roadmap for Reconfiguring Industrial Enterprises as a Consequence of the Global Economic Crisis," Journal of Service Science and Management, Vol. 3, No. 4, 2010, pp. 419-428. doi:10.4236/jssm.2010.34048

[2] I. H. Garbie, "Designing Cellular Manufacturing Systems Incorporating Production and Flexibility Issues," $\mathrm{PhD}$ 
Dissertation, The University of Houston, Houston, 2003.

[3] I. H. Garbie, H. R. Parsaei and H. R. Leep, "Measurement of Needed Reconfiguration Level for Manufacturing Firms," International Journal of Agile Systems and Management, Vol. 3, No. 1-2, 2008, pp. 78-92.

[4] U. Wemmerlov and D. J. Johnson, "Cellular Manufacturing at 46 User Plants: Implementation Experiences and Performance Improvements," International Journal of Production Research, Vol. 35, No. 1, 2007, pp. 29-49. doi: $10.1080 / 002075497195966$

[5] U. Wemmerlov and D. J. Johnson, "Cellular Manufacturing in the US Industry: A Survey of Users," International Journal of Production Research, Vol. 37, 1999, pp. 413-431.

[6] R. F. Marsh, S. M. Shafer and J. R. Meredith, "A Comparison of Cellular Manufacturing Research Presumptions with Practice," International Journal of Production Research, Vol. 37, No. 14, 1999, pp. 3119-3138. doi:10.1080/002075499190202

[7] S. Venkataramanaiah and K. Krishnaiah, "Hybrid Heuristic for Design of Cellular Manufacturing Systems," Production Planning and Control, Vol. 13, No. 3, 2002, pp. 274-283. doi:10.1080/09537280110073978

[8] O. Feyzioglu and H. Pierreval, "Hybrid Organization of Functional Departments and Manufacturing Cells in the Presence of Imprecise Data," International Journal of Production Research, Vol. 47, No. 2, 2009, pp. 343-368. doi: $10.1080 / 00207540802425898$

[9] M. B. Durmusoglu, "Analysis of the Conversion from a Job Shop System to a Cellular Manufacturing System," International Journal of Production Economics, Vol. 30-31, 1993, pp. 427-436. doi:10.1016/0925-5273(93)90110-7

[10] N. Gaither, G. V. Frazier and J. C. Wei, "From Job Shops to Manufacturing Cells," Production and Inventory Management Journal, Vol. 31, No. 4, 1990, pp. 33-36.

[11] G. A. Levasseur, M. M. Helms and A. A. Zink, "A Conversion from a Functional to a Cellular Manufacturing Layout at Steward, Inc.," Production and Inventory Management Journal, Vol. 36, No. 3, 1995, pp. 37-42.

[12] M. Liang and S. M. Taboun, "Converting Functional Manufacturing Systems into Focused Machine Cells-A Bicriterion Approach," International Journal of Production Research, Vol. 33, No. 8, 1995, pp. 2147-2161. doi: $10.1080 / 00207549508904808$

[13] G. C. Onwubolu, "Redesigning Job Shops to cellular Manufacturing Systems," Integrated Manufacturing Systems, Vol. 9, No. 5, 1998, pp. 377-382. doi:10.1108/09576069810238763

[14] S. Collett and R. J. Spicer, "Improving Productivity through Cellular Manufacturing," Production Inventory Management Journal, Vol. 36, No. 1, 1995, pp. 71-75.

[15] F. O. Olorunniwo and G. J. Udo, "Cell Design Practices in US Manufacturing Firms," Production and Inventory Management, Vol. 37, No. 3, 1996, pp. 27-33.

[16] M. Cantamessa and A. Turroni, "A Pragmatic Approach to Machine and Part Grouping in Cellular Manufacturing
System Design," International Journal of Production Research, Vol. 35, No. 4, 1997, pp. 1031-1050. doi:10.1080/002075497195524

[17] A. Baykasoglu, N. N. Z. Gindy and R. C. Cobb, "Capability Based Formulation and Solution of Multiple Objective Cell Formation Problems using Simulated Annealing," Integrated Manufacturing Systems, Vol. 12, No. 4, 2001, pp. 258-274. doi:10.1108/09576060110392560

[18] A. I. Abdelmola and S. M.Taboun, "A Simulated Annealing Algorithm for Designing Cellular Manufacturing Systems with Productivity Consideration," Production Planning and Control, Vol. 11, No. 6, 2000, pp. 589-597. doi:10.1080/095372800414151

[19] G. J. Nair and T. T. Narendran, "CASE: A Clustering Algorithm for Cell Formation with Sequence Data," International Journal of Production Research, Vol. 36, No. 1, 1998, pp. 157-179. doi:10.1080/002075498193985

[20] Y. Won and K. C. Lee, "Grouping Technology Cell Formation Considering Operation Sequences and Production Volumes," International Journal of Production Research, Vol. 39, No. 13, 2001, pp. 2755-2768. doi: $10.1080 / 00207540010005060$

[21] C. H. Cheng, C. H. Goh and A. Lee, "Designing Group Technology Manufacturing Systems Using Heuristics Branching Rules," Computers and Industrial Engineering, Vol. 40, No. 1-2, 2001, pp. 117-131. doi:10.1016/S0360-8352(00)00080-2

[22] A. M. Mukattash, M. B. Adil and K. K. Tahboub, "Heuristic Approaches for Part Assignment in Cell Formation," Computers and Industrial Engineering, Vol. 42, No. 2-4, 2002, pp. 329-431. doi:10.1016/S0360-8352(02)00020-7

[23] V. Ramabhatta and R. Nagi, "An Integrated Formulation of Manufacturing Cell Formation with Capacity Planning and Routing," Annals of Operations Research, Vol. 77, 1998, pp. 79-95. doi:10.1023/A:1018933613215

[24] W. E. Wilhelm, C. C Chiou and D. B. Chang, "Integrating Design and Planning Considerations in Cellular Manufacturing," Annals of Operations Research, Vol. 77, 1998, pp. 97-107. doi:10.1023/A:1018985630053

[25] Y. Yin and K. Yasuda, "Manufacturing Cells Design in Consideration of Various Production Factors," International Journal of Production Research, Vol. 40, No. 4, 2002, pp. 885-906. doi:10.1080/00207540110101639

[26] R. G. Askin and M. Zhou, "Formation of Independent Flow-Line Cells based on Operation Requirements and Machine Capabilities," IIE Transactions, Vol. 30, No. 4, 1998, pp. 319-329. doi:10.1080/07408179808966472

[27] S. Sofianopoulou, "Manufacturing Cells Design with Alternative Process Plans and/or Replicates Machines," International Journal of Production Research, Vol. 37, No. 3, 1999, pp. 707-720. doi:10.1080/002075499191742

[28] M. Chen, "A Mathematical Programming Model for System Reconfiguration in a Dynamic Cellular Manufacturing Environment," Annals of Operations Research, Vol. 77, 1998, pp. 109-128. 
doi:10.1023/A:1018917109580

[29] F. F. Boctor, "The Minimum-Cost, Machine-Part Cell Formation Problem," International Journal of Production Research, Vol. 34, No. 4, 1996, pp. 1045-1063. doi:10.1080/00207549608904949

[30] R. G. Askin, H. M. Selim and A. J. Vakharia,"A Methodology for Designing Flexible Cellular Manufacturing Systems," IIE Transactions, Vol. 29, No. 7, 1997, pp. 599-610. doi:10.1080/07408179708966369

[31] B. R. Sarker and Y. Xu, “ Designing Multi-Product Lines: Job Routing in Cellular Manufacturing Systems," IIE Transactions, Vol. 32, No. 3, 2000, pp. 219-235. doi:10.1080/07408170008963894

[32] R. Galan, J. Racero, I. Eguia and J. M. Garcia, “A Methodology for facilitating Reconfiguration in Mnaufacturing: the Move towards Reconfigurable Manufacturing Systems," International Journal of Advanced Manufacturing Technology, Vol. 33, No. 3-4, 2007, pp. 345-353. doi:10.1007/s00170-006-0461-2

[33] R. Galan, J. Racero, I. Eguia and J. M. Garcia, "A Systematic Approach for Product Families Formation in Reconfigurable Manufacturing Systems," Robotics and Computer Integrated Manufacturing, Vol. 23, No. 5, 2007, pp. 489-502. doi:10.1016/j.rcim.2006.06.001

[34] S. M. Saad "The Reconfiguration Issues in Manufacturing Systems," Journal of Processing Technology, Vol. 138, No. 1-3, 2003, pp. 277-283.

[35] M. R. Abdi and A. W. Labab, "Grouping and Selecting Products: The Design Key of Reconfigurable Manufacturing Systems (RMSs)," International Journal of Production Research, Vol. 42, No. 3, 2004, pp. 521-546. doi:10.1080/00207540310001613665

[36] S. Ahkioon, A. A. Bulgak and T. Bektas, "Cellular Manufacturing Systems Design with Routing Flexibility, Machine Procurement, Production Planning and Dynamic System Reconfiguration," International Journal of Production Research, Vol. 47, No. 6, 2009, pp. 1573-1600. doi:10.1080/00207540701581809

[37] S. Ahkioon, A. A. Bulgak and T. Bektas, "Integrated Cellular Manufacturing Systems Design with Production Planning and Dynamic System Reconfiguration," European Journal of Operational Research, Vol. 192, No. 2, 2009, pp. 414-428. doi:10.1016/j.ejor.2007.09.023

[38] W. Hachcha, F. Masmoudi and M. Haddar, "Combining Axiomatic Design and Designed Experiments for Cellular Manufacturing Systems Design Framework," International Journal of Agile Systems and Management, Vol. 3, No. 3-4, 2008, pp. 306-319.
[39] I. Alkattan, "Workload Balance of Cells in Designing of Multiple Cellular Manufacturing Systems," Journal of Manufacturing Technology Management, Vol. 16, No. 2, 2005, pp. 178-196. doi:10.1108/17410380510576822

[40] F. M. Defersha and M. Chen, "A Comprehensive Mathematical Model for the Design of Cellular Manufacturing Systems," International Journal of Production Economics, Vol. 103, No. 2, 2006, pp. 767-783. doi:10.1016/j.ijpe.2005.10.008

[41] H. A. Bashir and S. Karaa, "Assessment of Clustering Tendency for The Design of Cellular Manufacturing Systems," Journal of Manufacturing Technology Management, Vol. 19, No. 8, 2008, pp. 1004-1014. doi:10.1108/17410380810911754

[42] K. Das, R. S. Lashkari and S. Sengupta, "Reilability Considerations in the Design of Cellular Manufacturing Systems-A Simulated Annealing Based Approach," International Journal of Quality and Reliability Management, Vol. 23, No. 7, 2006, pp. 880-904. doi:10.1108/02656710610679851

[43] K. Das, R. S. Lashkari and S. Sengupta, "Reilability Considerations in the Design of Cellular Manufacturing Systems," International Journal of Production Economics, Vol. 105, No. 1, 2007, pp. 247-262. doi:10.1016/j.ijpe.2006.04.015

[44] S. Zolfaghari and M. Liang, "Machine Cell/Part Family Formation Considering Processing Times and Machine Capacities: A Simulated Annealing Approach," Computers and Industrial Engineering, Vol. 34, No. 4, 1998, pp. 813-823. doi:10.1016/S0360-8352(98)00112-0

[45] I. H. Garbie, H. R. Parsaei and H. R. Leep, "Introducing New parts into Existing Cellular Manufacturing Systems based on a Novel Similarity Coefficient," International Journal of Production Research, Vol. 43, No. 5, 2005, pp. 1007-1037. doi:10.1080/00207540412331270432

[46] S. S. Heragu, "Group Technology and Cellular Manufacturing," IEEE Transactions on Systems, Man, and Cybernetics, Vol. 24, No. 2, 1994, pp. 223-230. doi:10.1109/21.281420

[47] I. H. Garbie, H. R. Parsaei and H. R. Leep, “A Novel Approach for Measuring Agility in Manufacturing Firms," International Journal of Computer Applications in Technology, Vol. 32, No. 2, 2008, pp. 95-103. doi:10.1504/IJCAT.2008.020334

[48] Y. Koren, "The Global Manufacturing Revolution-Product-Process-business Integration and Reconfigurable Systems," 1st Edition, John Wiley and Sons, Hoboken, 2010 . 